\title{
Exploration and Exploitation of Mobile Apps for English Language Teaching: A Critical Review
}

\author{
Julius Irudayasamy ${ }^{1}$, Sani Yantandu Uba ${ }^{1} \&$ Carmel Antonette Hankins ${ }^{2}$ \\ ${ }^{1}$ Department of English Language and Literature, Dhofar University, Salalah, Oman \\ ${ }^{2}$ Foundation Program, Dhofar University, Salalah, Oman \\ Correspondence: Julius Irudayasamy, Department of English Language and Literature, Dhofar University, P.O \\ Box: 2509, Salalah-211, Oman.
}

Received: February 12, 2021

Accepted: March 22, 2021

Online Published: March 24, 2021

doi: $10.5539 /$ elt.v14n4p43

URL: https://doi.org/10.5539/elt.v14n4p43

\begin{abstract}
With the progression of various mobile technologies, mobile applications have tremendously increased, especially during the Covid-19 pandemic, and such applications have been exploited much in teaching and learning. This study explores the educational potential of using mobile applications in English language teaching (ELT) or Mobile Assisted Language Teaching (MALT). A critical review of the research in mobile applications in English language teaching is explored in this study, specifically from the published papers since 2015. Initially 131 articles were selected from ScienceDirect, SAGE, IEEEXplore, and Google Scholar. However, only 13 articles matched the inclusion criteria. These articles were analyzed and reviewed using the following categories: the role of mobile technology, pedagogical practices, research methodologies, the context of usage, and outcomes. The research found that mobile technologies in teaching language are increasing, and it is expected to rise in the future. In addition, teachers use different technologies to enhance English language teaching in the settings of inside and outside classrooms. During the COVID-19 pandemic, schools have closed indefinitely. This unexpected situation has forced students to stay at home, and online learning seems to grow exponentially. Thus, through this research review, significant educational outcomes are identified for future investigation practices.
\end{abstract}

Keywords: English language teaching (ELT), mobile applications, mobile technologies, mobile-assisted language teaching (MALT), mobile learning (m-learning), educational review

\section{Introduction}

Mobile technologies perform essential functions in most aspects of our daily life, offering usability, portability, and mobility. Users favour smaller devices with touch screen interfaces to traditional computers (Persson \& Nouri, 2018). Such preference affects many sectors of society, especially education. Last 10 years, users have witnessed rapid development in mobile technology (Zou \& Li, 2015). All-purpose daily-task computing services have been facilitated by mobile phone technology in various fields like commercial and non-commercial sectors. In this research, teaching and learning the English language fall under non-commercial sector. The use of mobile devices is not age restrictive, leading to an increase in the user base.

In the education field, mobile devices have had a significant impact, both in their usage and research. Mobile technology plays a significant role in English language learners' (ELL) development, and many countries are investing in ICT-enhanced educational projects, mainly due to the current English language scenario. Traditional and non-interactive teaching practices create a one-sided approach to teaching, and passive students memorize and learn English (Chang \& Hsu, 2011). Smartphones have numerous advantages compared to personal computers (PCs) in terms of size and weight which enable the users when they commute (Persson \& Nouri, 2018). Because of touch screen interface with most mobile phones, learners are able to interact with their peers and teachers and exchange their ideas. Such pedagogical approach allows teachers playing the role of facilitator and it increases the level of students' and teachers' participation (Clarke \& Svanaes, 2015).

Many studies show that mobile applications can provide potential educational possibilities for English Language Training (ELT) (Zou \& Li, 2015; Chang \& Hsu, 2011; Stockwell, 2010; Sadiq et al., 2019; Hoven \& Palalas, 2011). Most of these investigations try to determine the advantages of using mobile technologies in education, 
for instance, increased opportunities for independent learning, collaborative interaction, communication, and digital material (Clarke \& Svanaes, 2015; Nouri \& Pargman, 2016). Other investigations looked into identifying mobile applications' impacts on second language acquisition (Keyes et al., 2016; Rezaei et al., 2014). For example, Keyes et al. (2016) looked at the use of crossword puzzle; a game based application in teaching vocabulary to students of the second language, while Rezaei et al. (2014) found out that using mobile applications enhance the learning of vocabulary, class participation, and confidence among second language learners. English language teachers can use various mobile applications in formal and informal contexts to improve reading and listening comprehension, increase vocabulary, and help in grammar, spelling, translations, and grammar revision.

Mobile assisted language learning (MALL) has transformed learning and teaching in relevant fields (Rezaei et al., 2014; Zou \& Li, 2015; Persson \& Nouri, 2018). However, the investigation of systematic literature review on mobile applications for English language teaching (ELT) is weak and yet to be explored much. Hence, this study intends to report a methodical evaluation of several articles and critically analyzes the literature on mobile applications used in promoting the English language teaching and learning by examining various research trends in the last five years.

\section{Research Questions}

What are the significant ways mobile applications have been used as a potential tool for English language teaching, as shown by previous studies? The present critical review depends on the following sub-research questions.

- What are the roles of mobile technologies that underpin English language teaching in the previous studies?

- What are the identified pedagogical approaches?

- Which methodologies are used?

- What are the results and outcomes?

- What kinds of mobile technologies are used in English language teaching in terms of context?

\section{Background}

\subsection{Mobile Technologies}

In various aspects, mobile technology has different meanings; however, in almost all the aspects, mobile technology is based on wireless technology of wireless devices, which include mobile phones/smartphones, tablets PC, laptops, iPod, and Personal Digital Assistant (PDA) among others such as headphone, pend drive and mp3 players (Persson \& Nouri, 2018).

Because of lower prices than personal computers, portability, and mobility, mobile technologies have penetrated almost every aspect of people's daily lives. Mobile technology use in education facilitates teaching and learning, especially in foreign language teaching (Aziz et al., 2018). Over the past few years, there has been a rapid evolution of mobile technology. Since the beginning of the $21^{\text {st }}$ century, mobile technology has evolved. The previous standard mobile device featured a simple two-way pager, but has now evolved to being a mobile phone, handheld gaming console, instant messaging client, an embedded web browser, and GPS navigation device. There is an agreement among experts that the future of computer technology is found in mobile computing with wireless networking capabilities (Taylor et al., 2017). Tablet computer is becoming a more accessible way of utilizing mobile computing, and like smartphones, tablets are available on $3 \mathrm{G}$ and $4 \mathrm{G}$ networks.

Mobile technology has been successful because of benefits such as ubiquity and mobility that mobile devices serve to users. Today, mobile devices can play rich multimedia content allowing for advanced user interactivity, interact with cloud services, and run increasingly complex software (Aziz et al., 2018). New technologies and hardware such as multi-choice screens, accelerometers, Bluetooth, smartphone software applications, text messaging, mobile websites, Wi-Fi, GPS, and media capture ad creation tools are part of the mobile technology environment. The advantages of using mobile technology and new features make mobile technology rapidly penetrate people's daily lives.

\subsection{Mobile Application for ELT}

Mobile devices are an integral part of English language learning. These devices come in the form of tablet PCs, mobile phones, and iPods. These mobile devices allow teachers and students to access teaching and learning resources with mobile applications such as Wordable, which turns learning vocabulary into a competitive, fun 
game learners can play (Bekešová \& Romanová, 2019). Other mobile applications and technologies teachers can use in teaching the English language include Socrative, Tri Pro English, Fluent U, Google Docs, Get Set, Go! Phonics and Learn Languages with Ruby Rei (Wibbu) (Bekešová, 2019).

Mobile learning is different from traditional methods of teaching and learning. English language teachers constantly use mobile-assisted tools under various circumstances. Thus, this approach supports individual and collaborative network (Botha et al., 2010). Mobile learning shifts learning from teacher-centered teaching and learning to more learner-centered learning (Sung et al., 2015). Unlike traditional teaching and learning methods, mobile-assisted language learning with the latest technology endorses the informal learning process outside the classroom, allowing students learn autonomously (Persson \& Nouri, 2018). Such informal learning fosters independence and confidence when learning the English Language.

\section{Research on the Use of Technology to Support English Language Teaching}

\subsection{The History of CALL Falls under Three Phases}

Structural computer-assisted language learning (CALL), communicative CALL, and integrative CALL, as shown in diagram 1, also known as behaviorist CALL, started in the 1950s and developed through the 1970s (Warschauer, 1996). As an era of stimulus and response, the computer prompted language learners with questions (stimulus), and the learner provided answers (response) by providing correct answers through filling blanks or multiple choices (Warschauer, 1996). Numerous studies undertaken during this era treated the computer as a tutor that provided language learners with effective practice through drills, tutorials, and modeled dialogues (Warschauer, 1996; Yamazaki, 2014). Communicative CALL started in the 80s through the 90s and emerged as a reaction to the audio-lingual methods and Grammar-translation. Communicative CALL was based on exercises that the learner performed to practice English (Warschauer, 2000). It was based on the cognitive view of learning language through interaction, and learners could learn the language as an internal mental system. The third phase is the integrative CALL, which started in 2000, and it is based on two significant technological developments of the previous decade - the internet and multimedia significant (Warschauer, 2000).

The Three Stages of CALL

\begin{tabular}{l|l|l|l}
\hline Stage & $\begin{array}{l}\text { 1970s-1980s: } \\
\text { Structural CALL } \\
\text { Mainframe }\end{array}$ & $\begin{array}{l}\text { 1980s-1990s: } \\
\text { Communicative CALL } \\
\text { PCs }\end{array}$ & $\begin{array}{l}\text { 21st Century: } \\
\text { Integrative CALL } \\
\text { Multimedia and Internet }\end{array}$ \\
\hline $\begin{array}{l}\text { English-Teaching } \\
\text { Paradigm }\end{array}$ & $\begin{array}{l}\text { Grammar-Translation } \\
\text { \& Audio-Lingual }\end{array}$ & $\begin{array}{l}\text { Communicate } \\
\text { Language Teaching }\end{array}$ & $\begin{array}{l}\text { Content-Based, } \\
\text { ESP/EAP }\end{array}$ \\
\hline View of Language & $\begin{array}{l}\text { Structural (a formal } \\
\text { structural system) }\end{array}$ & $\begin{array}{l}\text { Cognitive } \\
\text { (a mentally-constructed } \\
\text { system) }\end{array}$ & $\begin{array}{l}\text { Socio-cognitive } \\
\text { (developed in social } \\
\text { interaction) }\end{array}$ \\
\hline $\begin{array}{l}\text { Principal Use } \\
\text { of Computers }\end{array}$ & Drill and Practice & $\begin{array}{l}\text { Communicative } \\
\text { Exercises }\end{array}$ & Authentic Discourse \\
\hline $\begin{array}{l}\text { Principal } \\
\text { Objective }\end{array}$ & Accuracy & And Fluency & And Agency \\
\hline
\end{tabular}

Figure 1. The stages of CALL, Warschauer, 1996; Kern \& Warschauer (2000, p. 64)

\subsection{Use of Mobile Applications for English Language Teaching Method}

Kim and Kwon (2012) regard Mobile Assisted Second Language Learning (MASLL) as a subset of both CALL and mobile learning. As people move from CALL to MASLL, this area is becoming a relevant field of research as supported by English language teaching and learning. MASLL offers English language learners the benefit of mobile technology portability, flexibility, manageability, and a variety of mobile applications (Kim \& Kwon, 2012; Persson \& Nouri, 2018). In addition, mobility, learning through real-life situations and self-regulated learning are not available in CALL whereas, all such access is possible in MASLL (Persson \& Nouri, 2018). Research supports the use of MASLL in teaching the English language as MASLL facilitates second language acquisition and development of linguistic knowledge as it focuses mainly on the acquisition of vocabulary, grammatical accuracy, listening comprehension, and speaking fluency (Persson \& Nouri, 2018; Viberg \& Grönlund, 2013; Kacetl \& Klímová, 2019). 


\section{Methodology}

\subsection{Data Collection}

- Database searched

The method was based on the literature review on the topic found in three acknowledged databases. The journals and electronic databases selected for this systematic review include ScienceDirect, SAGE, and IEEEXplore. Google Scholar was used as an additional source in systematic reviews, as according to Piasecki et al. (2017), Google Scholar cannot be used as the only source of the systematic review.

\section{- Examined terms}

The terms examined for this systematic review can be characterized into two clusters. Mobile applications and mobile assisted language teaching are grouped under category one. These terms included "mobile applications," or, "mobile-assisted teaching," "mobile-assisted language teaching," "MALT," and "mobile devices." The second group of search terms was associated with "English language teaching" and "second language learning." The following query was used to perform the search in various databanks. The query above allows the record to find out in any blend in group one and any such term or phrase in group two with the terms "mobile-assisted teaching" and "English language teaching."

\section{Articles Selection for Inclusion in the Review}

The articles that were to be considered appropriate for the review had to fulfill specific criteria for inclusion. These criteria include:

- The article must be published in English.

- Any article without an abstract was excluded.

- The study has to address English language teaching and learning and the use of mobile technologies and applications.

- The article should have been published in the journal or conference proceedings between 2015 and 2020. This period was selected to consider introducing and penetrating various mobile technologies such as iPad and other mobile applications for English language teaching. Additionally, other research articles similar to these were published either within this period or earlier. Only the recent articles were selected for this investigation because this systematic review should reveal only the latest analysis.

This systematic review focuses on mobile applications and technologies used in English language teaching. Furthermore, any article that investigates the use of computer-assisted language learning and teaching was excluded.

\section{Papers Identified and Selected}

One hundred thirty-one abstracts/titles of research articles were identified based on the identified keywords. Any paper that did not emphasize the use of mobile applications for teaching the English language was excluded. After considering only original peer-reviewed articles, the number dropped to 45 articles. After considering the criteria for inclusion and eliminating duplicate articles, 13 articles remained. Table 1 below shows the number of articles found in each database after applying the inclusion criteria. Google Scholar had the most number of articles before and after inclusion, followed by IEEE Explore then ScienceDirect. After considering the inclusion and exclusion criteria, all three articles from SAGE were excluded.

Table 1. Total number of classified papers in the database before and after applying the criteria for inclusion

\begin{tabular}{llll}
\hline database & \multicolumn{3}{c}{ frequency } \\
\hline & Before selection & After selection & \% after selection \\
ScienceDirect & $\mathbf{1 5}$ & $\mathbf{4}$ & $\mathbf{3 1 \%}$ \\
AGE & $\mathbf{3}$ & $\mathbf{0}$ & $\mathbf{0 \%}$ \\
IEEE Xplore & $\mathbf{1 7}$ & $\mathbf{1}$ & $\mathbf{8 \%}$ \\
Google Scholar & $\mathbf{9 6}$ & $\mathbf{8}$ & $\mathbf{6 2 \%}$ \\
Total & $\mathbf{1 3 1}$ & $\mathbf{1 3}$ & $\mathbf{1 0 0 \%}$ \\
\hline
\end{tabular}




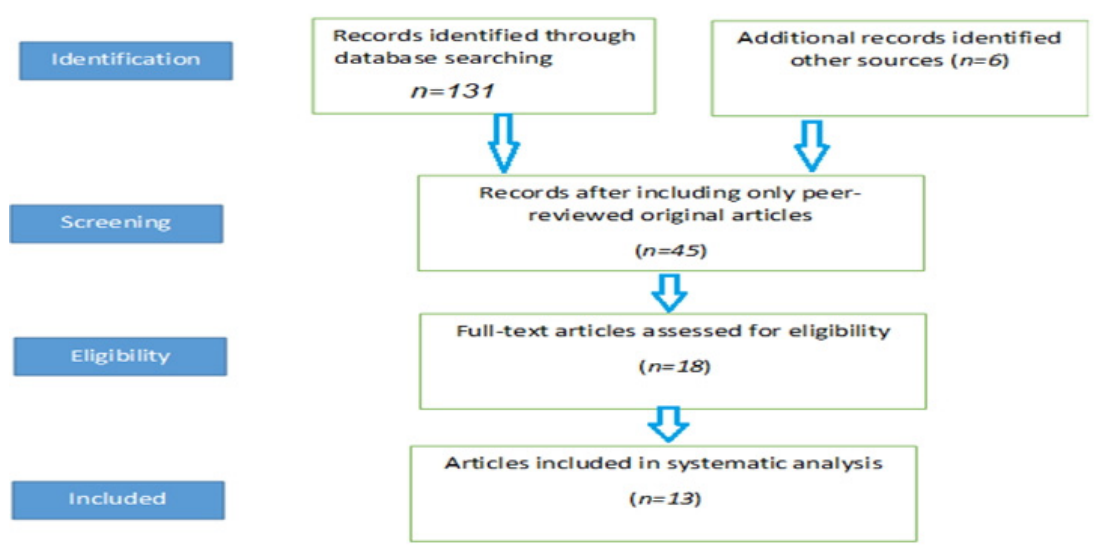

Figure 2. An overview of the selection procedure

\section{Data Analysis}

Coding. The coding method of the research articles that fulfill the inclusion criteria:

- Technology used

This analysis included the mobile technology used in assisting the teacher in teaching English. These criteria helped determine what technologies (software and hardware) and how they are used to teach the English language.

\section{- Pedagogical practices}

These codes helped to determine how learning enacted using mobile-assisted English language teaching was. It helped determine the activities or scenarios in which mobile applications are used to facilitate English language teaching.

- $\quad$ Research methodologies

This methodology looked at how the research questions in the respective research articles were studied. It included determining the primary research methodologies that were used in each paper.

- Context of usage

Largely this paper looked at the context in which the mobile application was used in teaching the English language. It sought to determine whether the applications were used in non-classroom indoors, in the classroom, outdoors, or across outdoors and indoors. These criteria helped the researcher to understand and explain the context in which these applications were used.

A sub-sample of 6 research papers out of 13 (46\%) was coded autonomously to assess the inter-related reliability with respect to the coding process. A .92 inter-related reliability score was obtained, indicating a good agreement between the coders.

\section{Results}

\subsection{Technology Used}

Table 2 below indicates the technology used as identified in the selected research articles. Fours research papers identified Smartphones (31\%), and the other four research articles identified tablets (31\%) as the used technology in teaching and learning the English language as a second language. Three research papers $(23 \%)$ identified cellphones as the used technology, while 2(15\%) identified PDAs as the used technology.

Table 2. The technology used in English Language learning and teaching

\begin{tabular}{lll}
\hline Technology Used & Frequency & Percentage \\
\hline Cell phones & 3 & $23 \%$ \\
Tablets & 4 & $31 \%$ \\
Smartphones & 4 & $31 \%$ \\
Personal Digital Assistant (PDA) & 2 & $15 \%$ \\
Total & 13 & $100 \%$ \\
\hline
\end{tabular}




\subsection{Pedagogical Practices}

Table 3 identifies the pedagogical practices. Six articles (46\%) identified mobile applications such as WhatsApp and WeChat improve and acquire English as a second language vocabularies. Two articles (15\%) found out that mobile technology helps students improve their reading, writing, listening, and speaking skills when learning English as a second language. Fours research papers $(31 \%)$ found out that mobile technologies are used to improve second language proficiency skills, while 1 article (8\%) found out that these technologies are used for peer and self-assessment of English language proficiency.

Table 3. Pedagogical practices in use mobile technology in English language learning and teaching

\begin{tabular}{lll}
\hline Pedagogical practices & Frequency & Percentage \\
\hline Improve and acquire vocabulary & 6 & $46 \%$ \\
Improve reading, writing, listening, and speaking skills & 2 & $15 \%$ \\
Improve second language proficiency skills & 4 & $31 \%$ \\
Peer-and self-assessment & 1 & $8 \%$ \\
Total & 13 & $100 \%$ \\
\hline
\end{tabular}

\section{Research Design}

Table 4 recognizes the research pattern used in the 13 selected articles. The experimental research method was the most used one with four research articles $(31 \%)$. One article (8\%) used a qualitative research design. Another article (8\%) used a systematic literature review. Both qualitative and quantitative research designs were used in 3 articles (23\%). A single article (8\%) out of 13 articles used a case study designed with qualitative and quantitative research methods used to collect data. Finally, three articles $(23 \%)$ did not identify the research method used.

Table 4. Research methods used to study the use of mobile technology in English language learning and teaching

\begin{tabular}{lll}
\hline Research Design & Frequency & Percentage \\
\hline Experimental Research Method & 4 & $31 \%$ \\
Qualitative Research Methodology & 1 & $8 \%$ \\
Systematic Literature review & 1 & $8 \%$ \\
Qualitative and Quantitative Research Methodology & 3 & $23 \%$ \\
Case Study Design & 1 & $8 \%$ \\
Method not identified & 3 & $23 \%$ \\
Total & 13 & $100 \%$
\end{tabular}

\section{Context of Usage}

Using the research papers shows that mobile technology is used in either outdoor or indoor contexts. Table 5 below shows the context in which mobile technology is used in English language learning and teaching. 4 articles $(31 \%)$ showed that mobile technology is mainly used outside the classroom (outdoors). Three articles (23\%) showed that mobile technology is used in the classroom (indoors). Three articles (23\%) indicated that mobile technology is used both indoors and outdoors to teach and learn English as a second language. However, three articles did not identify the context in which mobile technology is used to teach and learn the English language.

Table 5. Context of mobile technology usage in language learning and teaching

\begin{tabular}{lll}
\hline Context of Usage & Frequency & Percentage \\
\hline Outdoors (non-classroom setting) & 4 & $31 \%$ \\
Indoors (classroom setting) & 3 & $23 \%$ \\
Both Indoors and outdoors & 3 & $23 \%$ \\
Not specified & 3 & $23 \%$ \\
Total & 13 & $100 \%$ \\
\hline
\end{tabular}




\section{Data Analysis}

The analysis of articles using the inclusion criteria:

- Role of technology

This included the role mobile technology play in assisting the teacher in teaching English. These criteria helped determine what technologies (software and hardware) and how they are used to teach the English language.

- Pedagogical practices

These codes helped to determine how learning enacted using mobile-assisted English language teaching was. It helped determine the activities or scenarios in which mobile applications are used to facilitate English language teaching.

- Research methodologies

This looked at how the research questions in the respective research articles were studied. It included determining the primary research methodologies that were used in each paper.

- Context of usage

This looked at the context in which the mobile application was used in teaching the English language. It sought to determine whether the applications were used in non-classroom indoors, in the classroom, outdoors, or across outdoors and indoors. These criteria helped the researcher to understand and explain the context in which these applications were used.

- Outcomes

These codes sought to identify the overall impacts of using mobile-assisted English teaching and mobile devices in the process of English Language Teaching.

\section{Results}

\subsection{Role of Technology}

Overall, 13 original articles on the research topic were detected. These articles highlighted roles that mobile-assisted learning technology play using the application for English language teaching (Kukulska-Hulme et al., 2017). Cell phones and tablets were among the identified mobile devices (Kukulska-Hulme et al., 2017; Mohd Asraf \& Supian, 2017). Most of the research looked at the use of mobile devices such as cell phones, smartphones, tablets, and PDAs to assist teachers in teaching English Language (Rezaei et al., 2014; Mohd Asraf \& Supian, 2017; Zou \& Li, 2015; Jin, 2017). Few studies used PDA as a mobile device technology (Samaie et al., 2018; Zou \& Li, 2015).

\subsection{Pedagogical Practices}

Several of the 13 articles outlined the pedagogical practices when using the mobile application in English language teaching. Mobile applications were used to acquire and improve students' vocabulary (Mirzaei et al., 2018; Wu, 2019; Mohd Asraf \& Supian, 2017; Rezaei et al., 2014). Other studies reported that teachers could use applications such as WeChat and WhatsApp were generally used to help learners learn English as a second language (Samaie et al., 2018; Jin, 2017). Generally, mobile applications were used to help teachers teach the English language and students to acquire and improve their English vocabulary. Additionally, mobile applications were found to help learners improve their second language writing and reading skills, listening and speaking skills, and proficiency (Kukulska-Hulme et al., 2017; Kukulska-Hulme, Norris, \& Donohue, 2017). Mobile applications such as WhatsApp can be used for peer- and self-assessment of oral language proficiency (Samaie et al., 2018).

\subsection{Research Design}

The 13 articles used various research designs to investigate mobile applications in English language teaching. Several studies used experimental methods, e.g. (Mirzaei et al., 2018; Samaie et al., 2018; Wu, 2019; Zou \& Li, 2015). Hişmanoğlu et al. (2017) such as qualitative research methodology, while Gangaiamaran \& Pasupathi (2017) used a systematic literature review. Quantitative and qualitative methods were identified in two research articles (Abdi \& Cavus, 2019; Rezaei et al., 2014). However, several studies did not identify the research design used (Kukulska-Hulme et al., 2017; Jin, 2017; Kukulska-Hulme, Norris, \& Donohue, 2017) 


\subsection{Context of Usage}

These 13 articles identified the context- which mobile applications were used in mobile-assisted teaching. Some identified that mobile technology in teaching and learning was used in the classroom outdoor setting (Jin, 2017); (Samaie et al., 2018) and outdoors and indoors (Kukulska-Hulme et al., 2017; Hişmanoğlu et al., 2017). It is clear from the research that mobile applications are suitable in the classroom setting (indoors) and in non-classroom and beyond classroom settings (outdoors).

While teachers exploit mobile applications for second language learning, together with learners, teachers need to have the skills and resources to use the technology. Users need to consider the availability of mobile devices, associated cost, and Wi-Fi connection (Kukulska-Hulme et al., 2017)

The outcomes of these articles report various impacts on mobile-assisted learning, especially mobile applications, in teaching the English language. Some studies showed that both students and teachers preferred mobile applications to teach and learn English (Mirzaei et al., 2018). Mobile-assisted teaching helps learner improve their vocabulary and increase confidence in participating in the classroom (Rezaei et al., 2014), and they make learning enjoyable (Abdi \& Cavus, 2019; Gangaiamaran \& Pasupathi, 2017). However, some research showed that weak learners are reluctant to use mobile apps to learn English (Wu, 2019). Hişmanoğlu, Ersan, \& Çolak (2017) found that there are mixed teachers' perspectives towards the use of MASLL.

\section{Discussion}

As was indicated at the beginning of this systematic review, this paper aimed to study the potential use of mobile applications to enhance English language teaching by investigating the recent trends that have been done in the last five years (2015 to 2020). By using the research keywords, 131 articles related to MALL were identified. After eliminating the article that did not deal with mobile-assisted language teaching, 13 remained. After reading selected articles, it is evident that mobile assisted teaching, primarily mobile applications for English language teaching, is facing a profound change. English language teachers and researchers agree that mobile-assisted learning has a huge positive impact on English language teaching and learning (e.g., [Rezaei et al., 2014; Abdi \& Cavus, 2019; Mirzaei et al., 2018]). While mobile devices in teaching the English language appear to be rising, the primary issue lies in how these applications should be used. The coded research papers showed that tablets $(31 \%)$ and smartphones $(31 \%)$ were the most used technology in mobile-assisted learning and teaching.

\subsection{Technology Used}

In the review process, it was clear that the maximum number of chosen articles discussed smartphones and tablets as mobile technologies used in teaching and learning English as a second language. Cell phones and Personal digital assistances are also used to teach and learn the English language. Learners of English as a second language are being encouraged to use these technologies. Most studies identified various mobile technologies that are used in assisting English language teachers. These identified technologies include mobile phones, cell phones, PDAs, tablets, and smartphones. These mobile technologies are used to run mobile applications such as WeChat, WhatsApp, VLASTA, Wordable Socrative, Tri Pro English, Fluent U, Google Docs, Get Set, Go! Phonics and Learn Languages with Ruby Rei (Wibbu) (Bekešová, 2018). These mobile applications are used alongside various mobile technologies in various contexts such as indoor (classroom) and outdoor (non-classroom) settings to help learners acquire new English vocabulary and improve on their already acquired vocabulary. Teachers can use these technologies to supplement their English language teaching, which has been proven by the research to have positive results on learners and teachers. However, it has been suggested that teachers should assist weak learners on how to use the applications better to improve their English language.

Additionally, the technologies identified, such as mobile phones, cell phones, PDAs, tablets, and smartphones, provide touchscreen capabilities that create new pedagogical approaches that allow teachers to facilitate and enhance learners' participation (Clarke \& Svanaes, 2015). This pedagogical approach to learning was found to enhance second language acquisition (Samaie et al., 2018; Jin, 2017).

\subsection{Pedagogical Practices}

The coded research papers provided evidence that the use of MASLL helped to improve second language proficiency while focusing on English vocabulary learning, listening and speaking skills, and reading and writing skills. Most of the research papers (46\%) indicated that MASLL is used to help students acquire and improve their English language vocabulary. English second language learners can use various mobile applications to improve these identified skills (Bekešová \& Romanová, 2019; Kim et al., 2017). Additionally, mobile applications integrated in pedagogical practices allow teachers to plan second learning and facilitate teaching and learning in a real environment. Another pedagogical practice that uses MASLL enhances associating words with 
images or objects in the real-world and classroom (Gangaiamaran \& Pasupathi, 2017). However, it was clear that the use of MASLL for peer- and self-assessment was under-researched as only one article (8\%) that indicated the use of MASLL for peer and self-assessment.

\subsection{The Research Methodology Employed}

The review research papers showed that the most used research methodology in mobile technology research in teaching and learning English as the second language is experimental research design which represented $31 \%$ of the coded papers. It was noted that the research papers that used the experimental research design selected their data randomly, which minimized bias. Most of these papers used pre-and post-test to measure mobile technologies have an impact on teaching and learning the English language. The second most used research methodology in the reviewed papers is combining both qualitative and quantitative research designs representing $23 \%$ of the coded papers. A qualitative methodology was used to explore the effects, opinions, attitudes, and perceptions of English second language learners and teachers on their experience using mobile-assisted learning. Quantitative research design helped to generate knowledge and create understanding about the use of mobile technology. This mixed-method approach helped the researchers to collect both qualitative and quantitative data. One paper implemented the qualitative research design. Case study design and systematic literature review were used in one paper each.

\subsection{Context of Use of Mobile Technology}

It was necessary to understand how teachers and learners use mobile technology to teach and learn English as a second language. Most of the research articles coded showed that mobile-assisted learning takes place in non-classroom or setting. However, the remaining articles that indicated the context in which mobile technologies are used in teaching and learning the English language showed that teachers and learners are using the technology in the indoor and outdoor settings. In increased use of mobile technology outside the classroom setting shows that these technologies are making it possible for teachers and students to extend second language teaching and learning outdoors, creating an environment of continuous teaching and learning.

Furthermore, over 1.2 billion children are out of the classroom globally (Li \& Lalani, 2020). Naciri et al. (2020) confirm that mobile learning as a remote teaching strategy is an avoidable alternative during COVID-19. Schools have adopted virtual teaching and learning. Mobile learning during the pandemic provides English language learners with intuitive ways to identify the right collaborators, services, and contents at the right time in the right place based on the learners' surrounding contexts depending on place and time and the availability of learning services and resources, and the marching learning collaborators depending on the learners' needs (Yang, S. J., 2006; Wu et al., 2011; Clarke \& Svanaes, 2015). However, the unreliability of the internet or lack of technology is a barrier to ubiquitous learning during COVID-19 ( $\mathrm{Li} \&$ Lalani, 2020).

Hence, MASLL was found to support ubiquitous learning. With ubiquitous learning, second language learners access learning resources outside the classroom, enabling them to acquire learning resources and improve their English as a language learning and proficiency, for instance, as they travel during such a time of COVID 19 pandemic. Finally, universal learning allows learners to develop learning material that fits their learning needs and styles. Using blogs mobile applications and social media learners share materials with their peers. This approach increases collaboration between teachers and leaners (Clarke \& Syanaes, 2015).

\section{Conclusion}

This systematic literature review presents a comprehensive report on mobile-assisted language teaching (MALT), which is becoming a salient feature in the current and future education process. MALT provided a significant opportunity to teach the English language in a globalized world. MALT enhances English language teaching and learning both in a classroom setting and non-classroom setting and helps learners build their English vocabulary and confidence in the English language acquisition. It provided personalized learning, helping low-achieving learners to meet their learning goals. While MALT appears to be effective, it is subject to practical design, plan, and implementation and tailored to students' needs to deliver multiple language skills.

Mobile applications have transformed the learning strategies used in teaching the English language. The mobile learning strategies identified in the research underpinning ubiquitous learning enable teaching and learning the English language to take place limitlessly (seamlessly) anytime, anywhere. In any way, depending on the context of learning is determined by students' desires, needs, or characteristics. For instance, during the 2019-2020 COVID pandemic, online learning has become an alternative as schools close to curb the virus's spread. Online learning in such a context consists of activities that support classes online, onsite/offline. The principles of using 
the mobile application in ubiquitous English language learning signify adaptability, mobility, interactivity, accessibility, interoperability, interactivity, permanency, immediacy, context awareness, and pervasiveness.

However, despite the positive contribution of mobile application in teaching and learning English, teachers and students face challenges in designing and implementing activities, posting materials and resources for mobile learning. Teachers face challenges in supporting ubiquitous learning because of the lack of reliable real-time multimedia-rich communication and physical distance. Learning is a dynamic process, and any arising problems require quick resolution, which is less achievable in mobile-based learning.

This systematic literature review has some limitations. There is a limitation in the literature dealing with the use of mobile applications in English language teaching. While there is a wealth of research investigating the use of technology such as computers in learning a second language, the literature dealing with mobile applications for second language learning is limited. Therefore, future research should focus on using mobile applications in English language teaching. More research should also focus on using a laptop as a mobile device used to teach the English language.

\section{References}

Abdi, A. S., \& Cavus, N. (2019). Developing an Electronic Device to Teach English as a Foreign Language: Educational Toy for Pre-Kindergarten Children. International Journal of Emerging Technologies in Learning (iJET), 14(22), 29-44. https://doi.org/10.3991/ijet.v14i22.11747

Aziz, A., Hassan, M., Dzakiria, H., \& Mahmood, Q. (2018). Growing Trends of Using Mobile in English Language Learning. Mediterranean Journal Of Social Sciences, 9(4), 235-239. https://doi.org/10.2478/mjss-2018-0132

Bekešová, J., \& Romanová, I. (2019). Six technological innovations that changed English language teaching. ICTE Journal, 8(1), 30-38. https://doi.org/10.2478/ijicte-2019-0003

Botha, A., Herselman, M., \& van Greunen, D. (2010, October). Mobile user experience in a mlearning environment. In Proceedings of the 2010 Annual Research Conference of the South African Institute of Computer Scientists and Information Technologists, 29-38. https://doi.org/10.1145/1899503.1899507

Chang, C., \& Hsu, C. (2011). A mobile-assisted synchronously collaborative translation-annotation system for English as a foreign language (EFL) reading comprehension. Computer Assisted Language Learning, 24(2), 155-180. https://doi.org/10.1080/09588221.2010.536952

Clarke, B., \& Svanaes, S. (2015). Updated review of the global use of mobile technology in education. Techknowledge for Schools. $\quad$ Retrieved from https://www.kidsandyouth.com/pdf/T4S\%20FK\%26Y\%20Literature\%20Review\%2011.12.15.pdf

Gangaiamaran, R., \& Pasupathi, M. (2017). Review on use of mobile apps for language learning. International Journal of Applied Engineering Research, 12(21), 11242-11251. Retrieved from https://www.ripublication.com/ijaer17/ijaerv12n21_102.pdf

Hişmanoğlu, M., Ersan, Y., \& Çolak, R. (2017). Mobile-Assisted Language Teaching From Preparatory Program Efl Teachers' Perspectives. Bitlis Eren Üniversitesi Sosyal Bilimler Enstitüsü Dergisi, 6(2), 223-238. Retrieved from https://dergipark.org.tr/en/download/article-file/393399

Hoven, D., \& Palalas, A. (2011). (Re)Conceptualizing Design Approaches for Mobile Language Learning. CALICO Journal, 28(3), 699-720. https://doi.org/10.11139/cj.28.3.699-720

Jin, N. (2017, September). Mobile-assisted language learning: using WeChat in an English reading class. In International Symposium on Emerging Technologies for Education (pp. 500-506). Springer, Cham. https://doi.org/10.1007/978-3-319-71084-6_59

Kacetl, J., \& Klímová, B. (2019). Use of Smartphone Applications in English Language Learning -A Challenge for Foreign Language Education. Education Sciences, 9(3), 179. https://doi.org/10.3390/educsci9030179

Kern, R., \& Warschauer, M. (2000). Theory and practice of network-based language teaching. Network-based language teaching: Concepts and practice, 1-19. https://doi.org/10.1017/CBO9781139524735.003

Keyes, C., Shroff, R. H., \& Chow, E. (2016). Pedagogical foundations of a mobile application for language acquisition. Ubiquitous Learning: An International Journal,9(2), 1. Retrieved from https://repository.hkbu.edu.hk/ulip_ja/3/

Kim, H., \& Kwon, Y. (2012). Exploring smartphone applications for effective mobile-assisted language learning. Multimedia-Assisted 
https://doi.org/10.15702/mall.2012.15.1.31

Kukulska-Hulme, A., Lee, H., \& Norris, L. (2017). Mobile learning revolution: Implications for language pedagogy. The handbook of technology and second language teaching and learning, 217-233. https://doi.org/10.1002/9781118914069.ch15

Kukulska-Hulme, A., Norris, L., \& Donohue, J. (2017). Mobile Pedagogy for English Language Teaching: a Guide for Teachers. British Council, London (2015). Retrieved from https://www.teachingenglish.org.uk/sites/teacheng/files/E485\%20Mobile\%20pedagogy\%20for\%20ELT_v6 .pdf

Li, C., \& Lalani, F. (2020). The COVID-19 pandemic has changed education forever. This is how. World Economic Forum. Retrieved from https:/www.weforum.org/agenda/2020/04/coronavirus-education-global-covid19-online-digital-learning/

Mirzaei, S., Wilkinson, B., \& Wyra, M. (2018, December). Usability Testing of VLASTA: A Vocabulary Learning and Strategy Teaching App. In 2018 IEEE International Conference on Teaching, Assessment, and Learning for Engineering (TALE) (pp. 685-689). IEEE. https://doi.org/10.1109/TALE.2018.8615141

Mohd Asraf, R., \& Supian, N. (2017). Metacognition and mobile-assisted vocabulary learning. Arab World English Journal (AWEJ), 8(2), 16-35. https://doi.org/10.24093/awej/vol8no2.2

Naciri, A., Baba, M., Achbani, A., \& Kharbach, A. (2020). Mobile Learning in Higher Education: Unavoidable Alternative during COVID-19. Academia, 4(1), ep20016. https://doi.org/10.29333/aquademia/8227

Nouri, J., \& Pargman, T. C. (2016, September). When teaching practices meet tablets' affordances. Insights on the materiality of learning. In European Conference on Technology Enhanced Learning (pp. 179-192). Springer, Cham. https://doi.org/10.1007/978-3-319-45153-4_14

Persson, V., \& Nouri, J. (2018). A Systematic Review of Second Language Learning with Mobile Technologies. International Journal Of Emerging Technologies In Learning (Ijet), 13(02), 188. https://doi.org/10.3991/ijet.v13i02.8094

Piasecki, J., Waligora, M., \& Dranseika, V. (2017). Google Search as an Additional Source in Systematic Reviews. Science And Engineering Ethics, 24(2), 809-810. https://doi.org/10.1007/s11948-017-0010-4

Rezaei, A., Mai, N., \& Pesaranghader, A. (2014). The effect of mobile applications on English vocabulary acquisition. Jurnal Teknologi, 68(2), 73-83. https://doi.org/10.11113/jt.v68.2912

Sadiq, R. B., Cavus, N., \& Ibrahim, D. (2019). Mobile application based on CCI standards to help children learn English as a foreign language. Interactive Learning Environments, 1-16. https://doi.org/10.1080/10494820.2019.1579239

Samaie, M., Nejad, M., \& Qaracholloo, M. (2018). An inquiry into the efficiency of WhatsApp for self-and peer-assessments of oral language proficiency. British Journal of Educational Technology, 49(1), 111-126. https://doi.org/10.1111/bjet.12519

Stockwell, G. (2010). Using mobile phones for vocabulary activities: Examining the effect of platform. Language learning \& technology, 14(2), 95-110. Retrieved from https://www.learntechlib.org/p/74412/

Sung, Y., Chang, K., \& Yang, J. (2015). How effective are mobile devices for language learning? A meta-analysis. Educational Research Review, 16, 68-84. https://doi.org/10.1016/j.edurev.2015.09.001

Taylor, K., Takeuchi, L., \& Stevens, R. (2017). Mapping the daily media round: novel methods for understanding families' mobile technology use. Learning, Media And Technology, 43(1), 70-84. https://doi.org/10.1080/17439884.2017.1391286

Viberg, O., \& Grönlund, Å. (2013). A Cross-cultural analysis of users' attitudes toward the use of mobile devices in second and foreign language learning in higher education: A case from Sweden and China. Computers \& Education, 69, 169-180. https://doi.org/10.1016/j.compedu.2013.07.014

Warschauer, M. (1996). Computer-assisted language learning: An introduction. Multimedia language teaching, 320. Retrieved from https://www.ict4lt.org/en/warschauer.htm

Warschauer, M. (2000). The death of cyberspace and the rebirth of CALL. English Teachers' Journal, 53(1), 61-67. Retrieved from https://education.uci.edu/uploads/7/2/7/6/72769947/cyberspace.pdf

$\mathrm{Wu}$, R. (2019). The Effectiveness of MALT on Vocational College English Teaching. Journal of Language 
Teaching and Research, 10(3), 641-647. https://doi.org/10.17507/jltr.1003.01

Wu, T. T., Sung, T. W., Huang, Y. M., Yang, C. S., \& Yang, J. T. (2011). Ubiquitous English learning system with dynamic personalized guidance of learning portfolio. Journal of Educational Technology \& Society, 14(4), 164-180. Retrieved from https://www.learntechlib.org/p/75479/

Yamazaki, K. (2014). Toward integrative CALL: A progressive outlook on the history, trends, and issues of $\begin{array}{lcc}\text { CALL. TAPESTRY, 6(1), } & 6 . & \text { Retrieved } \\ \text { https://stars.library.ucf.edu/cgi/viewcontent.cgi? article=1042\&context=tapestry }\end{array}$

Yang, S. J. (2006). Context-aware ubiquitous learning environments for peer-to-peer collaborative learning. Journal of Educational Technology \& Society, 9(1), 188-201. Retrieved from https://www.jstor.org/stable/10.2307/jeductechsoci.9.1.188

Zou, B., \& Li, J. (2015). Exploring mobile apps for English language teaching and learning. In F. Helm, L. Bradley, M. Guarda, \& S. Thouësny (Eds.), Critical CALL - Proceedings of the 2015 EUROCALL Conference, Padova, Italy (pp. 564-568). https://doi.org/10.14705/rpnet.2015.000394

\section{Copyrights}

Copyright for this article is retained by the author(s), with first publication rights granted to the journal.

This is an open-access article distributed under the terms and conditions of the Creative Commons Attribution license (http://creativecommons.org/licenses/by/4.0/). 